BIOFARM

Jurnal Ilmiah Pertanian

ISSN Print: 0216-5430; ISSN Online: 2301-6442

Vol. 14, No. 2, Oktober 2018

\title{
Pengaruh Frekuensi dan Saat Aplikasi Beauveria bassiana terhadap Wereng Batang Coklat (Nilaparvata lugens Stal) pada Tanaman Padi (Oryza sativa L.)
}

\section{Effect of Frequency and Current Application of Beauveria bassiana on Brown Stems (Nilaparvata lugens Stal) on Rice (Oryza sativa L.)}

\author{
Moh. Isrin ${ }^{1 *}$ dan Anwar Fauzan ${ }^{2}$ \\ ${ }^{1}$ LPHP Kabupaten Pemalang \\ 2Program Studi Agrotenologi, Fakultas Pertanian, Universitas Pekalongan \\ *Korespondensi Penulis: moh.isrin65@yahoo.com
}

\begin{abstract}
ABSTRAK
Penelitian ini bertujuan untuk mengetahui pengaruh frekuensi dan saat aplikasi serta interaksinya terhadap Wereng Batang Coklat (Nilaparvata lugen, Stal) Pada Tanaman Padi (Oryza sativa, L). Penelitian dilaksanakan di desa Menjangan, Bojong, Pekalongan. Penelitian ini merupakan percobaan faktorial yang terdiri atas 2 faktor.Faktor pertama frekuensi yaitu kontrol, setiap 1 minggu, setiap 2 minggu, setiap 3 minggu. Faktor kedua pagi, siang, sore. Variabel pengamatan meliputi jumlah anakan per rumpun, jumlah malai per rumpun, panjang malai, jumlah gabah per malai, jumlah gabah hampa per malai, bobot gabah per 1000 butir, populasi wereng batang coklat, WBC yang terinfeksi jamur, intensitas serangan (\%), populasi predator. Hasil penelitian menunjukan bahwa frekuensi berpengaruh sangat nyata terhadap semua variabel pengamatan kecuali jumlah anakan per rumpun dan populasi predator. Perlakuan frekuensi terbaik adalah setiap 1 minggu. Saat aplikasi berbeda sangat nyata terhadap semua variabel pengamatan kecuali jumlah anakan per rumpun dan populasi predator. Perlakuan saat aplikasi terbaik adalah aplikasi sore. Terdapat interaksi yang sangat nyata anatara frekuensi dengan saat aplikasi terhadap semua variabel pengamatn kecuali jumlah anakan per rumpun dan populasi predator. Kombinasi terbaik diperoleh pada pada frekuensi setiap 1 minggu dengan saat aplikasi sore.
\end{abstract}

Kata kunci: B. bassiana, frekuensi dan saat aplikasi

\begin{abstract}
This study aims to determine the effect of the frequency and time of application as well as its interaction with Rod Brown planthopper (Nilaparvata Lugen Stal) At Rice (Oryza sativa L). The experiment was conducted in the village of Menjangan, Bojong, Pekalongan. This study is a factorial experiment consisting of two factors. The first factor is the frequency of control, every 1 week, every two weeks, every 3 weeks. The second factor in the morning, afternoon, evening. Variable observations include the number of tillers per hill, number of panicles per hill, panicle length, number of grains per panicle, number of grain hollow per panicle, weight of grain per 1000 grains, the population of brown plant hopper rod, WBC infected with the fungus, intensity of attack (\%), population predators. The results showed that the frequency of very significant effect on all variables except the observation of the number of tillers per hill and predator populations. Treatment best frequency is every 1 week. When an application is highly significant for all variables except the observation of the number of tillers per hill and predator populations. The treatment is currently the best application is the application of the afternoon. There is a very real interaction with the current frequency anatara application pengamatn against all variables except number of tillers per hill and predator populations. The combination terbak obtained on the best combination is achieved at a frequency of every one week with an afternoon time of application.
\end{abstract}

Keywords: B. bassiana, frequency, time of application

\section{PENDAHULUAN}

Padi (Oryza sativa) merupakan tanaman yang berasal dari India, Bangladesh, Thailand, Laos, Vietnam dan Cina (Listyanto, 2012). Padi merupakan bahan pangan pokok bangsa Indonesia. Jumlah penduduk Indonesia lebih dari 252.370 .792 jiwa, dengan laju pertumbuhan penduduk 1,21 persen per tahun dan jumlah konsumsi beras sebanyak
$114 \mathrm{~kg}$ per kapita per tahun. Sedangkan produksi padi 70,83 juta ton GKG setara 41 juta ton beras (Badan Pusat Statistik, 2014).

Peningkatan produksi beras terus diupayakan, namun sampai saat ini untuk kebutuhan dalam negeri belum tercukupi. Hal ini disebabkan salah satunya kehilangan hasil (panen, pasca panen dan gangguan OPT) (Badan Pusat Statistik, 2014). Budidaya 
tanaman padi mengalami beberapa faktor penghambat dan pembatas. Salah satu faktor tersebut adalah adanya Serangan OPT. Serangan OPT baik hama maupun penyakit relatif tinggi setiap tahun. Serangan tersebut belum dapat dikendalikan secara optimal sehingga menyebabkan kerugian yang cukup besar baik berupa kehilangan hasil, menurunkan mutu, terganggunya kontinuitas produksi, serta penurunan pendapatan petani. (Balai Peramalan Organisme Pengganggu Tumbuhan, 2007).

Hama tanaman padi yang cukup penting saat ini antara lain: penggerek batang padi (PBP), wereng batang coklat (WBC), tikus dan ganjur (Direktorat Perlindungan Tanaman Pangan, 2011). Wereng coklat dapat menimbulkan kerusakan ringan sampai berat pada hampir semua fase tumbuh, sejak fase pesemaian, anakan sampai fase masak susu (pengisian). Gajala wereng coklat pada individu rumpun dapat terlihat dari daun-daun yang menguning, kemudian tanaman mengering dengan cepat (seperti terbakar). Gajala ini dikenal dengan istilah hopperburn (Puslitbang Tanaman Pangan, 2008)

Upaya untuk mengurangi ketergantungan dengan penggunaan insektisida maka perlu adanya pengembangan agens antagonis dalam pengendalian wereng batang coklat. Salah satu agens antagonis dalam pengendalian wereng adalah Beauveria bassiana. Cendawan ini terdapat di semua lingkungan padi. B. bassiana memerlukan kelembaban yang tinggi dan lama untuk menumbuhakan spora-spora yang terbawa oleh angin atau air. Cendawan ini akan menyerang jaringan yang lunak dan cairan tubuh inang bila siap menghasilkan spora kembara. Spora itu kelihatannya seperti kapur putih pada tubuh wereng batang coklat (Pusat Penyuluh Pertanian, 2011).

Pemanfaatan $B$. bassiana mengalami beberapa kendala antara lain kurangnya pengetahuan petani tentang jenis hama dan patogen serangga, serta manfaat dan upaya mempertahankan viabilitas dan keefektifan cendawan dalam pengendalian hama, termasuk cara perbanyakan, penyiapan dan aplikasinya (Koswanudin dan Tri, 2014). Prayogo (2006) menyatakan bahwa untuk mempertahankan efektivitas $B$. bassiana dan untuk meningkatkan hasil pengendalian di lapang ialah dengan mempertinggi frekuensi aplikasi.

Waktu aplikasi Beauveria bassiana sebaiknya diaplikasikan pagi atau sore hari karena kemapanan entomopatogen yang merupakan makhluk hidup di lapangan sangat dipengaruhi oleh faktor lingkungan. Dalam aplikasinya diharapkan patogen tidak terkena cahaya matahari secara langsung karena sinar ultraviolet menyebabkan pathogen tidak aktif bahkan dapat membunuh pathogen dalam waktu yang relatif cepat. Kelembaban tinggi lebih meningkatkan keefektifan patogen (Untung, 2006).

Berdasarkan uraian di atas, maka dilakukan penelitian yang bertujuan untuk mengetahui frekuensi aplikasi Beauveria bassiana yang tepat terhadap wereng batang coklat pada tanaman padi (Oryza sativa), mengetahui saat aplikasi yang paling tepat Beauveria bassiana terhadap wereng batang coklat pada tanaman padi (Oryza sativa) dan mengetahui pengaruh interaksi antara frekuensi dan saat aplikasi Beauveria bassiana terhadap wereng batang coklat pada tanaman padi (Oryza sativa).

\section{BAHAN DAN METODE}

Penelitian telah dilaksanakan di Desa Menjangan Kecamatan Bojong Kabupaten Pekalongan pada ketinggian \pm 40 meter dari permukaan laut (dpl), mulai tanggal $17 \mathrm{Mei}$ 12 Agustus 2017. Rancangan yang digunakan dalam penelitian ini adalah RAK (Rancangan Acak Kelompok). Penelitian ini merupakan percobaan faktorial yang terdiri atas 2 faktor. Faktor pertama adalah frekuensi aplikasi Beauveria bassiana dan faktor kedua saat aplikaasi Beuvaria bassiana. Frekuensi aplikasi Beuvaria bassiana terdiri dari $\mathrm{F} 0=$ control, $\mathrm{F} 1=$ aplikasi setiap 1 minggu sekali, F2= aplikasi setiap 2 minggu sekali, F3= aplikasi setiap 3 minggu sekali. Saat aplikasi Beuvaria bassiana terdiri dari $\mathrm{T} 1=\mathrm{Pagi}, \mathrm{T} 2=$ siang, $\mathrm{T} 3=$ sore, dengan demikian terdapat 12 
kombinasi perlakuan, masing-masing kombinasi perlakuan diulang tiga kali, sehingga seluruhnya ada 36 satuan percobaan. Satuan percobaan terdiri dari lima tanaman sampel sehingga seluruhnya ada $36 \times 5=180$ tanaman sampel.

Variabel yang diamati meliputi : jumlah anakan maksimum, jumlah malai per rumpun, panjang malai, jumlah gabah per malai, jumlah gabah hampa per malai, bobot gabah per 1000 butir, populasi wereng batang coklat, WBC yang terifeksi jamur, intensitas serangan WBC, populasi predator. Pengukuran variabel pengamatan dilakukan setiap minggu, kecuali jumlah gabah per malai, jumlah gabah hampa per malai, bobot gabah per 1000 butir dilakukan saat panen.

Data yang diperoleh dianalisis dengan Uji F. Jika antara faktor yang dicoba terdapat perbedaaan nyata maka analisis dilanjutkan dengan Uji DMRT, untuk frekuensi dan saat aplikasi diuji menggunakan uji kontras orthogonal.

\section{HASIL DAN PEMBAHASAN}

\section{Pengaruh frekuensi aplikasi}

Hasil penelitian menunjukkan bahwa perlakuan frekuensi aplikasi berbeda sangat nyata terhadap semua variabel pengamatan kecuali jumlah anakan maksimum dan populasi predator tidak beda nyata. Hasil terbaik dari jumlah malai per rumpun, panjang malai, jumlah gabah per malai, jumlah gabah hampa per malai, bobot gabah per 1000 butir, populasi wereng batang coklat, WBC yang terifeksi jamur, intensitas serangan WBC, dicapai pada frekuensi aplikasi 1 minggu dengan jumlah malai per rumpun 19,04 buah, panjang malai $22,19 \mathrm{~cm}$, jumlah gabah per malai 177,51 butir, jumlah gabah hampa per malai 46,16 butir, bobot gabah per 1000 butir 27,11 gram, populasi wereng batang coklat 139,98 ekor per rumpun, WBC yang terifeksi jamur 126,44 ekor per rumpun, intensitas serangan WBC $26,53 \%$.

Tabel 1. Angka Rata-rata dan Analisis Statistik Data Penelitian Pengaruh Frekuensi dan Saat Aplikasi Beauveria bassiana terhadap Wereng Batang Coklat (Nilaparvata lugens stal) pada Tanaman Padi (Oryza sativa L.).

\begin{tabular}{|c|c|c|c|c|c|}
\hline Perlakuan & $\begin{array}{l}\text { Jumlah } \\
\text { anakan } \\
\text { maksimum } \\
\text { (batang) }\end{array}$ & $\begin{array}{l}\text { Jumlah } \\
\text { malai per } \\
\text { rumpun } \\
\text { (buah) }\end{array}$ & $\begin{array}{c}\text { Panjang } \\
\text { malai } \\
(\mathrm{cm})\end{array}$ & $\begin{array}{l}\text { Jumlah gabah } \\
\text { per malai } \\
\text { (butir) }\end{array}$ & $\begin{array}{c}\text { Jumlah gabah } \\
\text { hampa per } \\
\text { malai } \\
\text { (butir) }\end{array}$ \\
\hline \multicolumn{6}{|l|}{ Frekuensi (F) } \\
\hline $\mathrm{FO}=$ Kontrol & 25,56 & $13,62 \mathrm{a}$ & $17,23 \mathrm{a}$ & $171,91 \mathrm{a}$ & $121,91 \mathrm{~d}$ \\
\hline $\mathrm{F} 1$ = Aplikasi setiap 1 minggu & 26,89 & $19,04 d$ & $22,19 \mathrm{~d}$ & $177,51 \mathrm{~d}$ & $46,16 \mathrm{a}$ \\
\hline $\mathrm{F} 2=$ Aplikasi setiap 2 minggu & 25,89 & $16,02 \mathrm{c}$ & $21,73 \mathrm{c}$ & $173,98 \mathrm{c}$ & $70,27 \mathrm{~b}$ \\
\hline F3 = Aplikasi setiap 3 minggu & 24.67 & $14,71 \mathrm{~b}$ & $21,40 \mathrm{~b}$ & $173,24 \mathrm{~b}$ & $97,60 \mathrm{c}$ \\
\hline F Hitung & 1,86 tn & 44,23 ** & $377,60^{* *}$ & $12,99 * *$ & 886,24 ** \\
\hline F Tabel $5 \%$ & 3,44 & 3,44 & 3,44 & 3,44 & 3,44 \\
\hline F Tabel $1 \%$ & 5,72 & 5,72 & 5,72 & 5,72 & 5,72 \\
\hline DMRT $5 \%$ range 1 & $-7,83$ & 1,03 & 0,29 & 1,94 & 3,24 \\
\hline $\mathrm{KK}$ & & 6,67 & 1,23 & 1,14 & 3,95 \\
\hline \multicolumn{6}{|l|}{ Saat aplikasi (T) } \\
\hline $\mathrm{T} 1=$ pagi & 26,08 & $16,63 \mathrm{~b}$ & $22,2 \mathrm{~b}$ & $175,53 \mathrm{~b}$ & 65,68 a \\
\hline $\mathrm{T} 2=$ siang & 25,75 & $13,85 \mathrm{a}$ & $17,23 \mathrm{a}$ & $170,92 \mathrm{a}$ & $121,05 b$ \\
\hline T3 $=$ sore & 25,42 & $17,07 \mathrm{c}$ & $22,5 \mathrm{c}$ & $176,03 \mathrm{~b}$ & $65,22 \mathrm{a}$ \\
\hline F Hitung & $0,33 \mathrm{tn}$ & 32,68 ** & $1629,67^{\star *}$ & 24,09 ** & $1126,46^{\star *}$ \\
\hline F Tabel $5 \%$ & 4,33 & 4,33 & 4,33 & 4,33 & 4,33 \\
\hline F Tabel $1 \%$ & 7.94 & 7.94 & 7.94 & 7.94 & 7.94 \\
\hline DMRT $5 \%$ range 1 & - 7,83 & 0,58 & 0,26 & 1,68 & 2,80 \\
\hline & & 6,67 & 1,23 & 1,14 & 3,95 \\
\hline
\end{tabular}

Keterangan :

Angka-angka dalam kolom dan perlakuan yang diikuti dengan huruf yang sama menunjukkan tidak berbeda nyata berdasarkan Uji DMRT pada taraf $5 \%$. ${ }^{* *}=$ berbeda sangat nyata, ${ }^{*}=$ Berbeda nyata, tn $=$ tidak berbeda nyata. 
Peningkatan jumlah malai per rumpun, panjang malai, jumlah gabah per malai, bobot gabah per 1000 butir, wereng yang terinfeksi jamur serta dapat mengurangi jumlah gabah hampa per malai dan menekan populasi WBC dan intensitas serangan disebabkan pada semakin banyak frekuensi pemberian semakin rendah intensitas serangan hama WBC. Hal ini sesuai dengan pernyataan bahwa frekuensi aplikasi cendawan berulang dapat me- ngendalikan hama secara optimal (Prayogo dan Suharsono, 2005). Aplikasi setiap 1 minggu dapat menekan pertumbuhan dan perkembangan hama sehingga proses per-tumbuhan tanaman tidak terganggu. Selain itu pemberian $B$. Bassiana setiap 1 minggu akan menyebabkan kerapatan spora, spora yang menempel akan semakin banyak. Spora yang menempel semakin banyak akan mematikan serangga tersebut (Ferron, 1981).

Tabel 2. Angka Rata-rata dan Analisis Statistik Data Penelitian Pengaruh Frekuensi dan Saat Aplikasi Beauveria bassiana terhadap Wereng Batang Coklat (Nilaparvata lugens stal) pada Tanaman Padi (Oryza sativa L.).

\begin{tabular}{|c|c|c|c|c|c|}
\hline Perlakuan & $\begin{array}{l}\text { Bobot gabar } \\
\text { per } 1000 \\
\text { butir } \\
\text { (gram) }\end{array}$ & $\begin{array}{l}\text { Populasi Wereng } \\
\text { batang coklat } \\
\text { (ekor per } \\
\text { rumpun) }\end{array}$ & $\begin{array}{l}\text { WBC yang } \\
\text { terinfeksi jamur } \\
\text { (ekor per } \\
\text { rumpun) }\end{array}$ & $\begin{array}{c}\text { Intensitas } \\
\text { serangan } \\
\text { WBC } \\
(\%)\end{array}$ & $\begin{array}{l}\text { Populasi } \\
\text { predator }\end{array}$ \\
\hline \multicolumn{6}{|l|}{ Frekuensi (F) } \\
\hline $\mathrm{F} 0=$ Kontrol & $25,22 \mathrm{a}$ & $264,27 d$ & $00,00 \mathrm{a}$ & $57,01 d$ & 5,89 \\
\hline $\mathrm{F} 1$ = Aplikasi setiap 1 minggu & $27,11 d$ & $139,98 \mathrm{a}$ & $126,44 d$ & 26,53 a & 5,93 \\
\hline F2 = Aplikasi setiap 2 minggu & $26,21 \mathrm{~b}$ & $202,33 \mathrm{~b}$ & $48,84 \mathrm{c}$ & $30,50 \mathrm{~b}$ & 5,91 \\
\hline F3 = Aplikasi setiap 3 minggu & $25,99 \mathrm{~b}$ & $227,69 \mathrm{c}$ & $23,62 \mathrm{~b}$ & $42,46 \mathrm{c}$ & 5,89 \\
\hline F Hitung & 8,25 ** & 76,19 ** & $211,12^{* *}$ & $180,84^{* *}$ & $0,01 \mathrm{tn}$ \\
\hline F Tabel $5 \%$ & 3,44 & 3,44 & 3,44 & 3,44 & 3,44 \\
\hline F Tabel $1 \%$ & 5,72 & 5,72 & 5,72 & 5,72 & 5,72 \\
\hline DMRT $5 \%$ range 1 & 0,79 & 17,56 & 11,07 & 2,98 & $-9,68$ \\
\hline KK & 3,11 & 8,62 & 22,79 & 7,82 & \\
\hline \multicolumn{6}{|l|}{ Saat aplikasi (T) } \\
\hline $\mathrm{T} 1=$ pagi & $26,49 \mathrm{~b}$ & $180,32 b$ & $67,63 \mathrm{~b}$ & $30,75 \mathrm{~b}$ & 5,87 \\
\hline $\mathrm{T} 2=$ siang & $25,17 \mathrm{a}$ & $270,57 \mathrm{c}$ & $6,52 \mathrm{a}$ & $56,82 \mathrm{c}$ & 5,83 \\
\hline $\mathrm{T} 3=$ sore & $26,74 \mathrm{c}$ & $174,82 \mathrm{a}$ & $75,03 \mathrm{c}$ & $29,81 \mathrm{a}$ & 6,02 \\
\hline F Hitung & $13,03^{* *}$ & 107,28 ** & $132,09^{* *}$ & $301,39 * *$ & 0,35 \\
\hline F Tabel $5 \%$ & 4,33 & 4,33 & 4,33 & 4,33 & 4,33 \\
\hline F Tabel $1 \%$ & 7.94 & 7.94 & 7.94 & 7.94 & 7.94 \\
\hline DMRT $5 \%$ range 1 & 0,69 & 15,21 & 9,57 & 2,59 & $-9,68$ \\
\hline $\mathrm{KK}$ & 3,11 & 8,62 & 22,79 & 7,82 & \\
\hline
\end{tabular}

Keterangan :

Angka-angka dalam kolom dan perlakuan yang diikuti dengan huruf yang sama menunjukkan tidak berbeda nyata berdasarkan Uji DMRT pada taraf $5 \%$. ${ }^{* *}=$ berbeda sangat nyata, ${ }^{*}=$ Berbeda nyata, $\mathrm{tn}=$ tidak berbeda nyata.

Menurut Hasna dkk., (2012) B. bassiana setelah berhasil masuk ke dalam tubuh serangga akan mengeluarkan toksin beauverisin yang membuat kerusakan jaringan tubuh serangga, 2 hari kemudian serangga akan mati dan miselia cendawan akan tumbuh ke seluruh bagian tubuh serangga. Gejala awal infeksi $B$. bassiana pada serangga adalah serangga tidak makan, gerakan lemah, bergerak tidak menentu atau kehilangan gerak. Sejalan dengan penelitian Huffaker dan Messenger (1989) bahwa jamur entomopatogen memasuki inang dari bagian luar melalui kontak dengan integument serangga. Selanjutnya spora infektif akan melekat pada kutikula serangga inang yang peka, berkecambah membentuk tabung ke-cambah menembus kutikula serangga inang menuju ke hemocoel. Di dalam hemocoel jamur akan tumbuh dan berkembang dengan membentuk pertunasan (budding) tubuh hifa sampai seluruh ruang hemocoel terisi oleh massa hifa dan serangga inang mati (Purnomo,2005). Dengan demikian maka serangga tidak mampu merusak tanaman sehingga proses metabolisme tanaman dapat berjalan lancar dan 
fase pertumbuhan tanaman tidak terganggu.

Tabel 3. Angka Rata-Rata Interaksi antara Frekuensi dan Saat Aplikasi Beauveria bassiana terhadap Wereng Batang Coklat (Nilaparvata lugens stal) pada Tanaman Padi (Oryza sativa I.) Terhadap Jumlah Malai per Rumpun, Panjang Malai, Jumlah Gabah per Malai, Bobot Gabah per 1000 Butir.

\begin{tabular}{lccccc}
\hline $\begin{array}{l}\text { Kombinasi } \\
\text { Perlakuan }\end{array}$ & $\begin{array}{c}\text { Jumlah malai } \\
\text { per rumpun } \\
\text { (buah) }\end{array}$ & $\begin{array}{c}\text { Panjang } \\
\text { malai } \\
\text { (cm) }\end{array}$ & $\begin{array}{c}\text { Jumlah gabah } \\
\text { per malai } \\
\text { (butir) }\end{array}$ & $\begin{array}{c}\text { Jumlah gabah } \\
\text { hampa per malai } \\
\text { (butir) }\end{array}$ & $\begin{array}{c}\text { Bobot gabah per } \\
1000 \text { butir } \\
\text { (gram) }\end{array}$ \\
\hline F0T1 & $13,33 \mathrm{ab}$ & $17,13 \mathrm{a}$ & $171,27 \mathrm{ab}$ & $121,27 \mathrm{~d}$ & $25,33 \mathrm{ab}$ \\
F0T2 & $14,27 \mathrm{abc}$ & $17 \mathrm{a}$ & $170,2 \mathrm{a}$ & $120,33 \mathrm{~d}$ & $25,33 \mathrm{ab}$ \\
F0T3 & $13,27 \mathrm{a}$ & $17,57 \mathrm{a}$ & $174,27 \mathrm{bcd}$ & $124,13 \mathrm{~d}$ & $25,00 \mathrm{a}$ \\
F1T1 & $20.40 \mathrm{e}$ & $24,57 \mathrm{~d}$ & $180,40 \mathrm{e}$ & $10 \mathrm{a}$ & $28,00 \mathrm{de}$ \\
F1T2 & $14,33 \mathrm{abc}$ & $17,20 \mathrm{a}$ & $170,87 \mathrm{ab}$ & $121,27 \mathrm{~d}$ & $25,00 \mathrm{a}$ \\
F1T3 & $22,40 \mathrm{f}$ & $24,80 \mathrm{~d}$ & $181,27 \mathrm{e}$ & $7,20 \mathrm{a}$ & $28 ., 3 \mathrm{e}$ \\
F2T1 & $17,40 \mathrm{~d}$ & $23,87 \mathrm{c}$ & $176,20 \mathrm{~d}$ & $46,27 \mathrm{~b}$ & $26,64 \mathrm{bcd}$ \\
F2T2 & $13,40 \mathrm{abc}$ & $17,43 \mathrm{a}$ & $170,4 \mathrm{a}$ & $120,27 \mathrm{~d}$ & $25,00 \mathrm{a}$ \\
F2T3 & $17,27 \mathrm{~d}$ & $23,9 \mathrm{c}$ & $175,33 \mathrm{~cd}$ & $44,27 \mathrm{~b}$ & $27,00 \mathrm{cde}$ \\
F3T1 & $15,40 \mathrm{c}$ & $23,23 \mathrm{~b}$ & $174,27 \mathrm{bcd}$ & $85,20 \mathrm{c}$ & $26,00 \mathrm{abc}$ \\
F3T2 & $13,40 \mathrm{abc}$ & $17,17 \mathrm{a}$ & $172,20 \mathrm{abc}$ & $122,33 \mathrm{~d}$ & $25,33 \mathrm{ab}$ \\
F3T3 & $15,33 \mathrm{bc}$ & $23,70 \mathrm{bc}$ & $173,27 \mathrm{bcd}$ & $85,27 \mathrm{c}$ & $26,63 \mathrm{bcd}$ \\
FHitung & $10,92^{* *}$ & $162,04^{* *}$ & $4,23^{* *}$ & $223,17^{* *}$ & $3,18^{* *}$ \\
Ftabel 5\% & 2,55 & 2,55 & 2,55 & 2,55 & 2,55 \\
Ftabel 1\% & 3,76 & 3,76 & 3,76 & 3,76 & 3,76 \\
KK & 6,67 & 1,23 & 1,14 & 3,95 & 3,11 \\
\hline
\end{tabular}

Keterangan :

Angka-angka dalam kolom dan perlakuan yang diikuti dengan huruf yang sama menunjukkan tidak berbeda nyata berdasarkan Uji DMRT pada taraf $5 \%$. ${ }^{* *}=$ Berbeda sangat nyata, ${ }^{*}=$ Berbeda nyata, th = Tidak berbeda nyata.

\section{Pengaruh saat aplikasi}

Hasil penelitian menunjukkan bahwa perlakuan saat aplikasi berbeda sangat nyata terhadap semua variabel pengamatan kecuali jumlah anakan maksimum dan populasi predator tidak beda nyata. Hasil terbaik dari jumlah malai per rumpun, panjang malai, jumlah gabah per malai, jumlah gabah hampa per malai, bobot gabah per 1000 butir, populasi wereng batang coklat, WBC yang terifeksi jamur, intensitas serangan WBC, dicapai pada saat aplikasi sore dengan jumlah malai per rumpun 17,07 buah, panjang malai $22,5 \mathrm{~cm}$, jumlah gabah per malai 176,03 butir, jumlah gabah hampa per malai 65,22 butir, bobot gabah per 1000 butir 26,74 gram, populasi wereng batang coklat 174,82 ekor per rumpun, WBC yang terifeksi jamur 75,03 ekor per rumpun, intensitas serangan WBC $29,81 \%$.

Peningkatan jumlah malai per rumpun, panjang malai, jumlah gabah per malai, bobot gabah per 1000 butir, wereng yang terinfeksi jamur serta dapat mengurangi jumlah gabah hampa per malai dan menekan populasi WBC dan intensitas serangan disebabkan sore hari kelembaban tinggi, sehingga B.bassiana efektif dapat mematikan serangga. Hal ini sejalan dengan pendapat Lacey dan Goettel (1995) Keefektifan cendawan entomopatogen dipengaruhi oleh waktu aplikasi. Setelah diaplikasikan, cendawan entomopatogen memerlukan kelembapan yang tinggi untuk tumbuh dan berkembang. Cendawan entomopatogen sangat rentan terhadap sinar matahari khususnya sinar ultra violet. Bila terkena sinar matahari dalam waktu 4 jam, cendawan akan kehilangan viabilitas sebesar $16 \%$. Bila terkena sinar matahari 8 jam, viabilitas berkurang hingga di atas 50\%. Oleh karena itu, bila cendawan diaplikasikan pada musim kemarau perlu dihindarkan dari sinar matahari langsung dan sebaiknya aplikasi dilakukan pada saat kelembaban udara tinggi (sore hari) . Menurut Sheroze et al. (2003), bahwa kelembaban relatif $80 \%$ dan suhu $30^{\circ} \mathrm{C}$ merupakan kondisi yang baik untuk pertumbuhan jamur B. bassiana. (Soetopo dan Indrayani, 2007). Pengaruh suhu terutama pada perkembangan koloni dan konidia yang berkecambah. Pada 
suhu tinggi koloni lebih lambat dan konidia yang berkecambah menurun, sedangankan pada suhu rendah koloni dan konidia meningkat (Inglish et al. 1996). Konidia jamur entomopatogen akan memanfaatkan senyawa -senyawa yang terdapat pada lapisan integumen serangga. Sehingga jamur akan me- nembus tubuh serangga dan serangga akan terinfeksi dan dapat menyebabkan kematian (Tanada \& Kaya, 1993). Keberhasilan aplikasi ini dapat menekan kerusakan tubuh dan kematian tanaman, sehingga selama proses pertumbuhan tanaman tidak terganggu.

Tabel 4. Angka Rata-Rata Interaksi antara Frekuensi dan Saat Aplikasi Beauveria bassiana terhadap Wereng Batang Coklat (Nilaparvata lugens sta) pada Tanaman Padi (Oryza sativa l.) Terhadap Populasi WBC, WBC yang terinfeksi Jamur, Intensitas Serangan.

\begin{tabular}{lccc}
\hline $\begin{array}{l}\text { Kombinasi } \\
\text { Perlakuan }\end{array}$ & $\begin{array}{c}\text { Populasi Wereng batang coklat } \\
\text { (ekor per rumpun) }\end{array}$ & $\begin{array}{c}\text { WBC yang terinfeksi jamur } \\
\text { (ekor per rumpun) }\end{array}$ & $\begin{array}{c}\text { Intensitas serangan } \\
\text { WBC } \\
(\%)\end{array}$ \\
\hline F0T1 & $254,33 \mathrm{c}$ & $0 \mathrm{a}$ & $55,57 \mathrm{e}$ \\
F0T2 & $274,40 \mathrm{~cd}$ & $0 \mathrm{a}$ & $57,73 \mathrm{e}$ \\
F0T3 & $264,07 \mathrm{~cd}$ & $0 \mathrm{a}$ & $57,73 \mathrm{e}$ \\
F1T1 & $87,27 \mathrm{a}$ & $167,2 \mathrm{~d}$ & $12,60 \mathrm{ab}$ \\
F1T2 & $265,40 \mathrm{~cd}$ & $198,4 \mathrm{e}$ & $55,90 \mathrm{e}$ \\
F1T3 & $67,27 \mathrm{a}$ & $13,73 \mathrm{a}$ & $11,10 \mathrm{a}$ \\
F2T1 & $183,93 \mathrm{~b}$ & $70,93 \mathrm{c}$ & $18,53 \mathrm{c}$ \\
F2T2 & $249,47 \mathrm{c}$ & $7,53 \mathrm{a}$ & $55,9 \mathrm{e}$ \\
F2T3 & $173,60 \mathrm{~b}$ & $68,07 \mathrm{c}$ & $17,07 \mathrm{bc}$ \\
F3T1 & $195,73 \mathrm{~b}$ & $32,40 \mathrm{~b}$ & $36,3 \mathrm{~d}$ \\
F3T2 & $293,00 \mathrm{~d}$ & $4,80 \mathrm{a}$ & $57,73 \mathrm{e}$ \\
F3T3 & $194,33 \mathrm{~b}$ & $33,67 \mathrm{~b}$ & $33,33 \mathrm{~d}$ \\
FHitung & $16,48^{* *}$ & $44,08^{* *}$ & 39,63 \\
Ftabel 5\% & 2,55 & 2,55 & 2,55 \\
Ftabel 1\% & 3,76 & 3,76 & 3,76 \\
KK & 8,62 & 22,79 & 7,82 \\
\hline Ke & & &
\end{tabular}

Keterangan :

Angka-angka dalam kolom dan perlakuan yang diikuti dengan huruf yang sama menunjukkan tidak berbeda nyata berdasarkan Uji DMRT pada taraf $5 \%$. ${ }^{* *}=$ Berbeda sangat nyata, ${ }^{*}=$ Berbeda nyata, tn $=$ Tidak berbeda nyata.

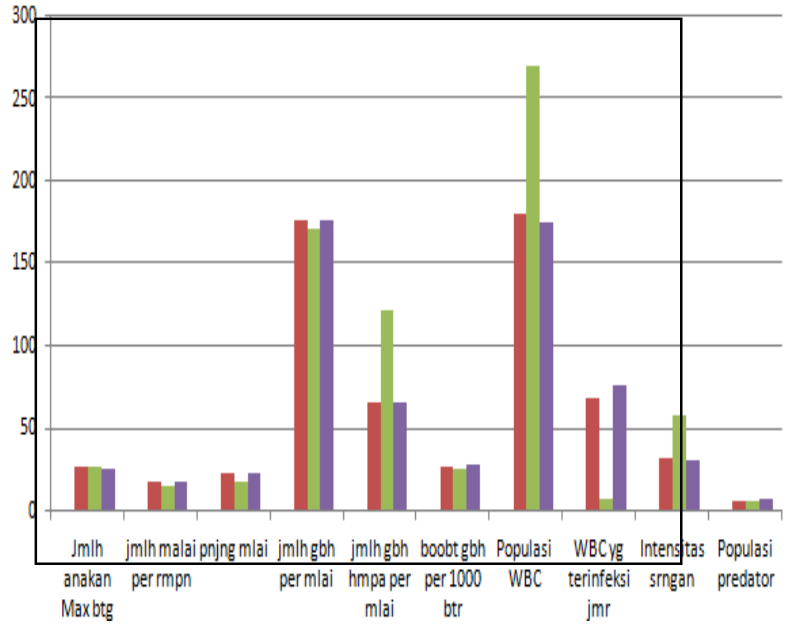

Gambar 1. Pengaruh Frekuensi Aplikasi terhadap 10 Variabel Pengamatan

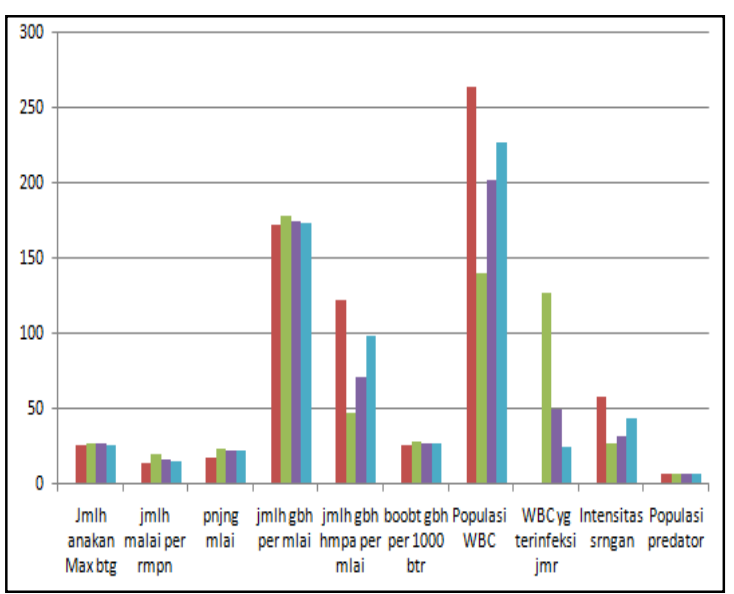

Gambar 2. Pengaruh Saat Aplikasi terhadap 10 Variabel Pengamatan 


\section{Pengaruh interaksi antara frekuensi dan saat aplikasi Beauveria bassiana}

Hasil penelitian menunjukkan bahwa terjadi interaksi berbeda sangat nyata antara frekuensi dengan saat aplikasi terhadap semua varabel pengamatan kecuali jumlah anakan maksimum dan populasi predator. Kombinasi terbaik adalah pada perlakuan frekuensi setiap 1 minggu dengan aplikasi sore (F1T3), hal ini terjadi disebabkan adanya hubungan saling mendukung dengan aplikasi setiap 1 minggu maka B.bassiana lebih efektif apalagi dilakukan saat sore hari saat suhu dan kelembaban mendukung. Menurut Prayogo (2006), untuk mempertahankan efektivitas $B$. bassiana dan untuk meningkatkan hasil pengendalian di lapangan ialah dengan mempertinggi frekuensi aplikasi. Aplikasi pada sore hari (setelah pukul 16.00) mampu menyebabkan kematian hama. Kematian hama akan menurunkan serangan pada tanaman padi. Tanaman padi merupakan tanaman pangan bersifat semusim, sehingga sekali aplikasi cendawan harus mampu menginfeksi dan mengkolonisasi serangga hama sasaran. Oleh karena itu, kerapatan konidia yang dibutuhkan lebih tinggi. B.Bassiana diaplikasikan sore akan lebih efektif karena konodia tidak akan rusak. Temperature dan kelembaban adalah factor abiotik yang sangat berpengaruh terhadap pertumbuhan konidia B.bassiana, tetapi cahaya melalui panjang gelombang sinar ultraviolet juga berpotensi merusak konidia sehingga aplikasi sore hari dapat menghindari kerusakan (Soetopo dan Indrayani,2007). Serangga yang mati maka tidak akan mengganggu tanaman padi pada fase tumbuh dari fase pesemaian sampai masak susu (pengisian).

Hasil penelitian menunjukkan bahwa tidak terjadi interaksi antara frekuensi dengan saat aplikasi terhadap variable jumlah anakan maksimum dan populasi predator, hal ini terjadi karena masing-masing perlakuan berpengaruh secara terpisah, sejalan dengan pendapat Rahmi dan Jumiati (2007) bahwa bila pengaruh interaksi tidak nyata, maka disimpulkan bahwa diantara faktor-faktor perlakuan tersebut berpengaruh secara terpisah. Sehingga anatara frekuensi dengan saat aplikasi) tidak terdapat hubungan saling mempengaruhi.

\section{KESIMPULAN}

1. Frekuensi aplikasi berpengaruh sangat nyata terhadap semua variabel yang diamati, kecuali jumlah anakan maksimum dan populasi predator. Frekuensi aplikasi setiap 1 minggu memberikan hasil terbaik pada pertumbuhan dan produksi tanaman padi.

2. Saat aplikasi berpengaruh sangat nyata terhadap semua variabel yang diamati, kecuali jumlah anakan maksimum dan populasi predator. Saat aplikasi sore memberikan hasil terbaik pada pertumbuhan dan produksi tanaman padi.

3. Terdapat interaksi antara frekuensi dan saat aplikasi terhadap semua variabel kecuali jumlah anakan maksimum dan populasi predator. Kombinasi terbaik dicapai pada frekuensi setiap 1 minggu dengan saat aplikasi sore hari.

\section{DAFTAR PUSTAKA}

Badan Pusat Statistik. 2014. Statistik Padi Indonesia. http://www.bps.go.id. (Diakses pada 5 Desember 2015).

Balai Peramalan Oraganisme Pengganggu Tumbuhan. 2007. Petunjuk Peramalan Hama Dan Penyakit Tanaman Pangan dan Hortikultura. Depatemen Pertanian, Direktorat Jenderal Bina Produksi Pangan, Balai Peramalan Oraganisme Pengganggu Tumbuhan. Jatisari.

Direktorat Perlindungan Tanaman Pangan. 2011. Wereng Batang Coklat dan Upaya Pengendaliannya. Departemen Pertanian, Jakarta.

Feron P. 1981. Pest Control by the fungi Beauveria and Metharizium. In H.D. Burges.(Ed), Microbial Control of pest and plantdiseases. New York, Academic Press. 465-482 
Hasnah, Susanna, dan S Husin. 2012. Keefektifan Cendawan Beauveria Bassiana Vuill terhadap Mortalitas Kepik Hijau Nezara Viridula L. pada Stadia Nimfa dan Imago. J. Floratek 7: 13-24.

Huffaker CB, Messenger PS. 1976. Theory and Practice of Biological Control. Diterjemahkan oleh Soeprapto $M$. 1989. Teori dan Praktek Pengendalian Biologis. Universitas Indonesia Press.

Koswanudin, D dan Tri, E.W. 2014. Keefektifan Bioinsektisida Beauveria bassiana terhadap hama wereng batang coklat (nilaparvata lugens), walang sangit (leptocorisa oratorius), pengisap polong (nezara viridula) dan (riptortus linearis). Prosiding Seminar Nasional Pertanian Organik, Bogor 18-19 Juni 2014.

Lacey, L.A. and M.S. Goettel. 1995. Current developments in microbial control of insect pests and prospects for the early 21 st century. Entomophaga (40): 3-27.

Prayogo Y, 2006. Upaya Mempertahankan Keefektifan

Cendawan

Entomopatogen Untuk Mengendalikan Hama Tanaman Pangan. Jurnal Libang Pertanian, 25 (2): 47-54.

Prayogo Y. dan Suharsono, 2005. Optimalisasi Pengendalian Hama Pengisap Polong Kedelai (Riptortus linearis) Dengan Cendawan Entomopatogen Verticillium lecanii. Jurnal Litbang Pertanian, 24 (4): 123130.
Purnomo H. 2005. Patogen Serangga. (Online). (http://www.patogen Serangga. pdf) Diakses 17 Maret 2017.

Pusat penyuluh Pertanian. 2011. Serangga, Laba-laba dan pathogen yang membantu. Pusat penyuluhan pertanian, Badan penelitian dan pengembangan pertanian, international rice research institute.

Puslitbang Tanaman Pangan. 2008. Masalah Lapang Hama, Penyakit, Hara pada Padi. Puslitbang Tanaman Pangan,BB Padi, BB2TP, BPTP, dan IRRI.

Rahmi, A dan Jumiati. 2007. Pengaruh Konsentrasi dan Waktu Penyemprotan Pupuk Organik Cair Super ACI terhadap Pertumbuhan dan Hasil Jagung Manis. Agritrop, Vol.26 (3):105 -109 .

Sheroze A, Rashid A, Shakir AS, Khan SM. 2003. Effect of Bio-control Agents on Leaf Rust of Wheat and linfluence of Different Temperature and Humidity Levels onTheir Colony Growth. Int. J. of Agri. Biol. 5(1):83-85.

Soetopo, D. dan I. Indrayani. 2007. Status Teknologi dan Prospek Beauveria bassiana untuk Pengendalian Serangga Hama Tanaman Perkebunan yang Ramah Lingkungan. Jurnal Perspektif, vol. 6 (1):29- 46.

Tanada, Y. and H.K. Kaya. 1993. Insect Pathology. Academic Press, Inc. New York. PP.459- 493. 